DE DE GRUYTER OPEN
Journal of Intercultural Management

Vol. 6, No. 4, part II, December 2014, pp. 87-97

DOI 10.2478/joim-2014-0059

Katarzyna Łukasik ${ }^{1}$

Politechnika Częstochowska

\title{
The Importance of Organizational Culture for Entrepreneurship in Family Businesses
}

\begin{abstract}
The article discusses the issue of the importance of organizational culture for business development of family businesses. In connection with the above, there will be presented the essence and types of organizational culture, leading to the entrepreneurial attitudes of all members of family business. The theoretical part of the article is supported by empirical research, carried out in a selected group of family businesses in various industries in Czestochowa.
\end{abstract}

Keywords: organizational culture, entrepreneurship, family businesses, impact, development

\section{Introduction}

Organizational culture plays an important role in the life of every organization, and in case of a family business, its significance is gaining a greater attention. The main reason of the above are deeply rooted, long-established traditions and values. On the one hand, they may constrain innovative activities of an organization, due to multiple copying clichés of the functioning and on the other, with appropriate flexibility of an organization and creativity of a younger generation, they may lead to creative plans and future decisions. The above leads to the conclusion that an entrepreneurial family business requires appropriate potential and changes, the ones which are both more and less visible, and elements of organizational culture with a focus on pro-innovative thinking.

Therefore, the task of organizational culture is to set certain limits, bringing about the isolation of an organization from others, giving it its peculiar character, 
its manner of functioning, regarding the market and clients. On the other hand, for people working there, it gives a sense of identity while constituting the reference point and determining their everyday behavior and decisions, leading to a common interest. Its existence is independent of ownership or organization size. On the other hand, in case of entrepreneurship, the situation is rather different, i.e. either the company shows entrepreneurial attitudes and benefits from it or not. While using the definition by S. Sudol [2008, p.10] either the company possesses some entrepreneurial features (also concerning the employees individually), manifesting themselves in its processes, projects, activities or the way of management, or it just remains on the market with the remnants of the possibility. According to K. Chudy: "Moreover, entrepreneurship refers to the attitudes of an entrepreneurial person, the person who, actually, takes up their own business, manages it, accepts their own failures. An important role of an entrepreneur results from the fact that it is them who discover consumers' new needs, introduce new products onto the market, discover new markets, technologies, reorganize the existing enterprises or create new ones, achieve goals effectively or implement new management methods, above all, the ones of managing people and leading to increase in work efficiency" [2011, p. 41]. Different ways of understanding entrepreneurship result in lack of precise definition of this phenomenon. In the view of the above, how does entrepreneurship develop in family businesses?

From the perspective of large, world family businesses (like Ford), the phenomenon of entrepreneurship in family businesses is not a concept entirely unknown. The situation is different in case of Polish family companies which, only 25 ago, ran a stable and profitable business, while not expecting that, to them, the consequence of "free market" would be a necessity to face trans-national competitors, e.g. the Asian ones. For many local entrepreneurs, who inherited their businesses, it was a moment of the outbreak of a real revolution, which often resulted in the fall, or in the best case, the change of business profile. (From the point of view of the discussed entrepreneurship, this was the beginning of paying special attention to the environment of an organization, also the distant one). And so, out of the chaos of the unknown and frequently accidental activities, there emerged the first patterns of specific actions, among others, what tools should be used to beat competitors effectively, what techniques and marketing tricks will attract clients the fastest, how to build a strong relationship with a client, and finally the most important, where from and how to gain knowledge for creating innovative products or services. Nowadays, the knowledge of management, marketing or economic laws is no longer a significant problem in the performance of functions in family businesses but very often it happens that their activities are not connected with organizational culture which, by some, is simply treated as internal atmosphere of a company. If a family business requires from its employees to adopt and conform to 
values, principles, views and norms of behavior in force in an organization, while simultaneously emphasizing efficiency, success and creating innovative solutions, it should provide its employees with appropriate working conditions and possibilities of their development. Entrepreneurial attitudes often have their origin in free workplaces, not bound by the excessive control, and organizational culture should create and support such developmental working conditions.

Therefore, the aim of the present paper is to examine the importance of organizational culture for creating entrepreneurship in family businesses. The research is based on the literature studies and the empirical results obtained from the conducted survey.

\section{Organizational culture in the importance of entrepreneurship in family businesses}

Family businesses occupy an important place in the economy of Poland and other countries. Simultaneously, they are the oldest form of running a business activity and as some claim, they constitute a very durable and strong pillar of Polish economy [Kempa 2011, p.73; http://www.forbes.pl/artykuly/sekcje/Wydarzenia/ pawlak--firmy-rodzinne-trwalym-filarem-gospodarki,25356,1]. In the opinion of the above author, apart from the basic functions, i.e. production, sales of products or services, there is concern for family ties and satisfying the needs of family members. Therefore, a family business is a specific creation of a business activity which, with the proper management, meets financial and non-financial objectives. This, in case of this type of activity, means, on the one hand, waiting for steady profit and achieving success (it is often a long-term plan on well-thought investments), and on the other, tightening family ties, creating one community and securing the succession. The practice shows, however, that the effective succession for two or more generations in family businesses is not so easy. The chances for a family business to survive long enough to be passed to the hands of another generation are not big. And so the research shows that only $30 \%$ of the companies will last to the next generation and only $10 \%$ to the third generation, whereas merely $3-5 \%$ of the companies will survive to the fourth generation [Fleming 2006, p. 8; Tomski 2011, pp. 137-150]. There are a lot of reasons of this phenomenon, beginning with the displacement by foreign competitors, discussed above, through family conflicts, lack of a successor, ending with lack of ideas for further existence of the company. In spite of many obstacles, these $30 \%$ of the family businesses found a way to stay on the market for another generation. It is possible to acknowledge that, to a large extent, it is the result of well-established strategy, supported with values, principles and rules of operating, bringing about creative thinking and aiming at searching for the latest solutions.

It is also worth remarking that family businesses in Poland, most frequently, are not such large organizations, which were formally established and for the 
functioning of which a very formal nature of business is needed. Because of that, less formalized family organizations are more flexible, they adapt to changes more easily, they are not so bureaucratic, which brings about easiness of decision-taking among family members and easier establishment of goals, and also the correction of their potential if needed [http://firmyrodzinne.pl/warto-przeczytac/bazawiedzy/45-artykuly/70-charakterystyka-firm-rodzinnych-cz1.html]. In family businesses, which is important, there is stronger identification with the values of the enterprise itself or internal beliefs as for the accomplishment of the company's mission. Successors, who are to continue a family business, take over responsibilities resulting from the main values, constituting the identity of the company. They often focus on the standards they got accustomed to. However, it does not mean the rejection of innovativeness. This consists in preserving the values which lead to the establishment of the company, its success, the ones which are in the awareness of family members who create business as well as the remaining unrelated employees. Their maintenance is important from the point of view of the company identity.

In case of creating entrepreneurial environment, it is important to change the attitude of employees, their way of thinking, which will no longer consist in outdated, obsolete solutions but contrary, in searching for unknown, far from beaten, tracks. Activity or otherwise understood creativity of the people in a family business must result from not only the need of a situation but also the future image of the company and the assessment of its position among the competitors. This means, among others, the openness for the needs of the market and flexibility, the rate of reaction to changes, sometimes taking risk. An important role is also played by the factors which are closely related to organizational culture like, among others, [Antoszkiewicz 2003, p.11]:

- initiative,

- persistence in pursuing goals,

- corporate social responsibility,

- ability to search for opportunities and occasions,

- ability to learn fast (training and self-development of employees),

- openness for information from the outside,

- social and family conditions,

- leadership skills,

- motivating employees (rewarding for the performance),

- identification and assessment of strengths and weaknesses of an organization.

To activate and develop the above factors, it is important to pay attention to the cultural aspects of family businesses. The determinant is building up a common trust between the senior/founder of the company and the successors and employees who are not relatives. Moreover, there must be a common goal for their activities, focusing on the actions and involvement of all the participants of the business. 
Collectivism, characteristic of Japanese companies, should be reflected in running a common business by the family.

According to A. Puto [2013, pp.25-26], the companies from the SME sector, including the family ones, must fight for their autonomy and the management ought to allow employees to take decisions corresponding to the principles and values of the entire company. Therefore, for the development of creative potential of employees of a family business, there is a need for appropriate management, directed towards the opportunities of the company development, which is consistent with appropriate atmosphere and non-creating communication barriers.

\section{Entrepreneurial organizational culture of family businesses in the research results}

The questionnaire was used to carry out the assessment of the importance of organizational culture for entrepreneurship in family businesses. The obtained results allowed to specify whether and how organizational culture influences the entrepreneurship of these companies. In the questionnaire there were used closed-ended questions and the research was anonymous and it was a pilot study supplemented with direct interview.

The research was conducted in the four selected family businesses located in the city of Czestochowa in December 2013. 56 correctly filled in questionnaires were obtained. Among those questioned, there were $34 \%$ of women and $66 \%$ of men (the respondents were both family members and the remaining, not related, employees).

To assess the problem under consideration, the responses to the following questions, presented in the below figures, were analyzed.

Figure 1.The understanding of organizational culture

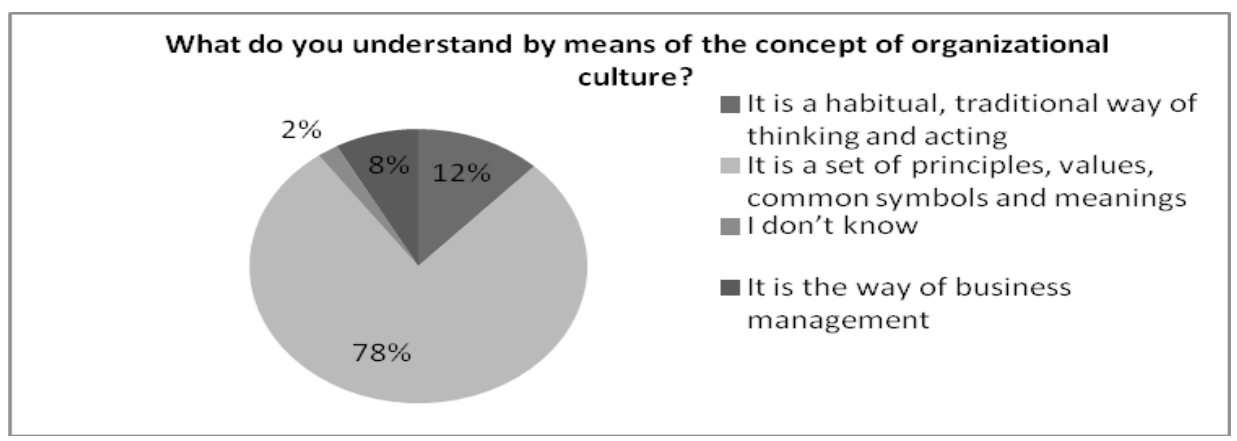

Source: The author's own research based on the conducted studies.

The obtained answer concerning the knowledge of the concept of organizational culture, among the employees of the analyzed family businesses, seem to be satisfactory. 
As much as $78 \%$ of the respondents indicated the most important elements of the culture in the company, i.e. principles, values, common symbols and meanings. Therefore, the knowledge of this concept is not unknown but, what is more, during direct contact, the respondents are able to list a few principles, rules or values (even though they are not written down formally e.g. in the form of the code of ethics) in the company, while simultaneously acknowledging them as rightful and giving an exceptional character to a family business. $12 \%$ of those questioned regarded organizational culture as habitual and traditional ways of thinking, which, in a simplified way, also characterizes the concept under research. Only $8 \%$ understand the term of organizational culture as a way of management and $2 \%$ are not able to assess what it consists in. However, in the next question: Is there strong attachment to the values and traditions in the company?, $61 \%$ of the respondents answered 'yes' whereas $39 \%$ - 'no'. During the direct interview they explained that they are aware of the existence of organizational culture in their companies but, e.g. they treat traditions, holidays and other events in their workplace more like entertainment than the culture.

Then, there was assessed the atmosphere in the family businesses under research. In spite of the fact of receiving many positive opinions, i.e. $32 \%$ of the respondents evaluated the atmosphere and moods in their companies as very good, $48 \%$ as good, $18 \%$ as average and only $2 \%$ as very bad. During the direct interview the employees (mainly the successors) complained about excluding them in the decision-making processes, sometimes ignoring their ideas or requests. From the perspective of entrepreneurship, such organizational climate does not seem to be advantageous, which the managers of the family businesses were informed about after conducting the research.

Figure 2. The assessment of the appreciation of the involvement of the employees in the performance in the companies under research

\section{In your opinion, are the efforts of the employees, which bring about the company success, appreciated and adequately rewarded?}

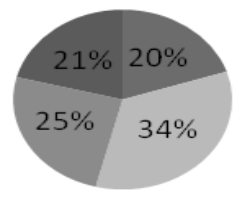

definitely yes rather yes rather not

no

Source: The author's own research based on the conducted studies. 
Another question (Fig. 2) referred to the assessment of the contribution and efforts put in everyday struggle with tasks by the family business employees and whether this contribution, bringing about the company success, is appreciated. In this case, the proportions of the responses were spread evenly, i.e. $21 \%$ of the respondents feel appreciated in their job, 34\% answered 'rather yes', and 25\% 'rather not' and also the same number answered 'no' (21\%). Adequately to the previous question, also in this case the situation in the family businesses under consideration is not regarded as exceptionally motivating to further activities and the involvement of the employees in a common goal. Therefore, there are required some changes in the values and certain rules e.g. rewarding the subordinates the successors sometimes forget about. It is essential for the development of employees, their efficiency and aiming at innovativeness, even in a small family business.

Figure 3. The attitude towards risk

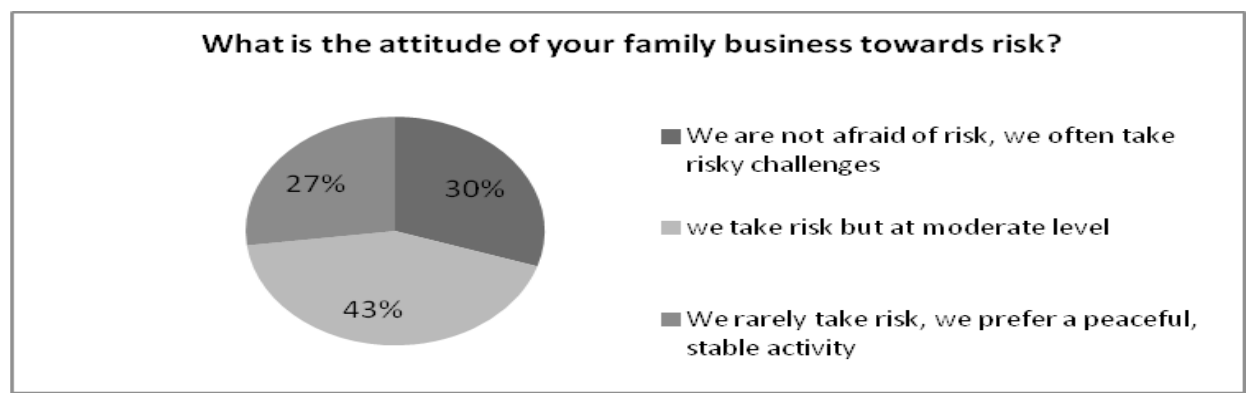

Source: The author's own research based on the conducted studies.

The above Figure (Fig. 3) indicates that the analyzed family businesses, in the respondents' opinion, in most cases (43\%), are careful as for risk-taking. $27 \%$ of those questioned think that their companies often take risky actions, and $30 \%$ point out at their rarity, while choosing the stable activity. According to such authors as R. Cantillon, J.S. Milla or G. Knight [Gostkowska-Dźwig 2011, p. 9] willingness to take risk is the integral part of an entrepreneurial organization. Therefore, the family businesses under research ought to more frequently search for market opportunities and take risk, while appraising their own potential.

In the opinion of the respondents of the family businesses under consideration, $66 \%$ think that their organizational culture influences the development of entrepreneurship in the company (Fig. 4). 20\% express no opinion and $14 \%$ do not associate the increase in entrepreneurship in the company with organizational culture. While referring to the theoretical considerations on the problem, receiving $66 \%$ of the 'yes' responses, seems to be satisfactory. For the analyzed group of employees, the culture in the company is expressed in entrepreneurial behavior of the employees. 
Figure 4. The influence of organizational culture on entrepreneurship

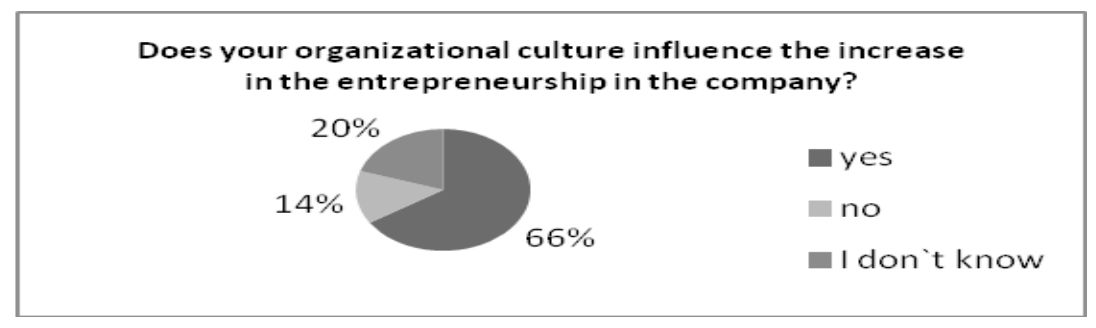

Source: The author's own research based on the conducted studies.

Figure 5. The assessment of the conditions for the development of entrepreneurial attitudes

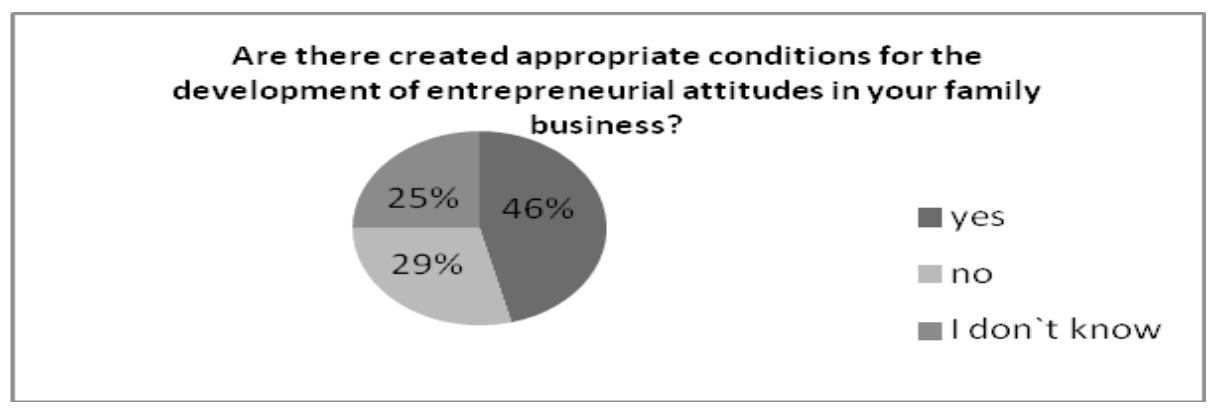

Source: The author's own research based on the conducted studies.

In another question, the respondents were asked about creating the conditions for the development of entrepreneurial attitudes in their family businesses (Fig. 5). In the opinion of $46 \%$ of the respondents, in their companies there are created the conditions favorable for the above. The responses to another question state what kind of conditions were most frequently indicated. On the other hand, for almost the same amount of the respondents, i.e. 29\% (the answer 'no') and 25\% ('I don't know'), there are no visible conditions favorable for the expansion of entrepreneurship in the company. This may be the evidence e.g. of lack of knowledge, by the employees, on the undertaken development activities by the managers of the company, and promoting them inside the company or, actually, ignoring the market situations by the managers and not paying attention to the needs for development. 
Table 1. The factors determining the entrepreneurial attitude in the family businesses under consideration

\begin{tabular}{|c|c|}
\hline Factors & $\begin{array}{c}\text { The percentage of responses } \\
\text { (in case of a positive answer } \\
\text { to the previous question, the } \\
\text { respondents selected 3 factors } \\
\text { conditioning the entrepreneurial } \\
\text { attitude in their company) }\end{array}$ \\
\hline Employees attend specialized training (symposia, conferences) & $15 \%$ \\
\hline Employees are encouraged to self-development & $73 \%$ \\
\hline There are introduced some improvements in the company if \\
needed & $61 \%$ \\
\hline There are promoted some positive (socially ethical) attitudes & $36 \%$ \\
\hline Employees possess professionally prepared workplaces & $46 \%$ \\
\hline Creative employees are always appreciated & $50 \%$ \\
\hline There is preferred the participative management style (giving \\
more discretionary powers to employees)
\end{tabular}

Source: The author's own research based on the conducted studies.

According to Table 1, the entrepreneurial working conditions are not unfamiliar to family businesses. The companies under research, above all, concentrate on encouraging their employees to self-development (73\%) (in two of the examined companies, this was partial funding of gaining expertise). $61 \%$ of those questioned indicated that their company introduces, if possible, the improvements in workplaces to increase efficiency (e.g. by automation, computerization). The respondents also pointed out that their enterprises are willing to take new challenges (50\%) and their creativity is appreciated (50\%). What is important, in the examined companies, the attention is drawn to the promotion of socially ethical attitudes (36\%), which is also significant for the evolution of organizational culture and incorporating, with regard to the employees, some ethical values referring to the internal and external environment of the company. Only 19\% of the respondents pointed to using participative management style by the companies. This situation, from the point of view of family businesses, is not favorable since this style could stimulate, to a greater extent, the employees to be creative or to show their hidden skills in different situations.

\section{Conclusions}

Paying attention to the role of culture in creating entrepreneurial work environment is becoming increasingly important for the Polish business from the SME sector. It is not possible to be an entrepreneurial family business without appropriate cultural attitude. There is strong cultural potential in Polish family 
businesses, though it is sometimes suppressed by conservative and traditional habits. Any entrepreneurial activities of the company require openness, flexibility or pluralism of the ideas and this, in turn, makes managers and their subordinates build up inspiring, creative work environment and use employees' intellectual potential the most considerably. From the perspective of the temporary pace of change, the priority for the majority of family businesses should be pro-innovative and entrepreneurial attitude and organizational culture ought to operate in here as a supportive element, giving an entrepreneurial direction to the activities. The discussed determinants of organizational/entrepreneurial culture, clearly indicate the necessity of significant changes of many important values, norms and organizational rules, for unifying people's work in the entrepreneurial environment. The conducted research presented the situation of the four Czestochowa family businesses which, in spite of many problems, crises, have been staying on the market for at least two generations. This has been considerably influenced by organizational culture which, in these four cases, has evolved along with the market needs, while aiming at creating the development opportunities of the companies. The successors preserved the most important values of organizational culture but they also did not forget about introducing changes, which is extremely important for the contemporary businesses.

\section{References}

Antoszkiewicz J.D. (2003), Rozwijanie przedsiębiorczości - wybrane koncepcje [in:] K. Piech, M. Kulikowski (eds.), Pržedsiebiorczoś́́: szansa na sukces ržadu, gospodarki, pržedsiębiorstw, spoteczeństwa, Instytut Wiedzy, Warszawa.

Chudy K. (2011), Istota przedsięiorczósci w aspekcie spotecznej odpowiedzialności [in:] H. Kościelniak, S. Gostkowska-Dźwig [eds.], Przeedsiebiorczosć́ we wspótczessnych procesach gospodarowania. Studia przypadkón, wyd. WZPCzęst, Częstochowa.

Fleming Q.J. (2006), Tajniki pržetrwania firmy rodzinnej, Wyd. Helion, Gliwice.

Gostkowska Dźwig (2011), Kreowanie wartości pržedsiebiorstwa jako jeden z. elementón przejawn przedsiębiorczósci organizacji na rynku [in:] H. Kościelniak, S. Gostkowska-Dźwig [eds.], Przedsiębiorczosć́ we wspótczesnych procesach gospodarowania. Studia przypadkón, wyd. WZPCzęst, Częstochowa.

Kempa E. (2011), Strategia rožnoju firm rodżinnych w sektorze MMSP, [in:] A. Marjański [ed.], Firmy rodzinne - determinanty funkcjonowania i rozpoju. Strategia zarz̨adzania przedsiebiorstwem rodzinnym, „Przedsiębiorczość i Zarządzania”, Tom XII, Zeszyt 7, Wyd. SWSPiZ, Łódź.

Lawniczak-Stadnik A. (2008), O kulturach firm amerykańskich [in:] A. Stankiewicz-Mróz, Jarosław Lendzion [eds.], Wyzwania dla zarzadzania zasobami ludzkimi w sytuacji przemian na rynku pracy, Wyd. Media Press, Lódź.

Puto A. (2013), Czynniki hamujace rožuój wspótczesnych małych i średnich przedsiębiorstw, [in:] O. Seroka-Stolka [ed.], Wspótczesne problemy zarzadzania matym i średnim przedsiębiorstwem, wyd. WWZPCz, Częstochowa. 
Sudoł S. (2008), Pržedsiębiorczośc - jej pojmowanie, typy i czynniki ja kształtujace, „Problemy Zarządzania”, No 2.

Tomski P. (2011), Programowanie przyszłości biznesu w oparciu o wiezi rodzinne - wybrane problemy sukecesji, Przedsiębiorczość i Zarządzanie, t. XII, z. 7, Seria SWSPiZ, Wydawnictwo SAN, Łódź.

http://firmyrodzinne.pl/warto-przeczytac/baza-wiedzy/45-artykuly/70-charakterystykafirm-rodzinnych-cz1.html, accessed: 11.02.2014

http://www.forbes.pl/artykuly/sekcje/Wydarzenia/pawlak--firmy-rodzinne-trwalym-filarem-gospodarki,25356,1; accessed:11.02.2014 